\title{
Chemical factors affecting the intestinal absorption of zinc in vitro and in vivo
}

\author{
BY C. J.SEAL AND F. W. HEATON \\ Department of Biological Sciences, University of Lancaster, Lancaster LA1 4YQ
}

(Received 12 January 1983 - Accepted 29 March 1983)

\begin{abstract}
1. Everted sacs of rat duodenum and ileum were used to study the effect of anions and organic ligands on the absorption of zinc. The uptake per unit weight of tissue was greater in duodenum than ileum, and it was influenced by the $\mathrm{Zn}$ concentration and $\mathrm{pH}$ of the incubation medium.

2. The $\mathrm{Zn}$ uptake from inorganic salts in simple buffered medium varied in the order zinc sulphate $>$ zinc chloride $>$ zinc phosphate. Zinc acetate was more effective and zinc citrate less effective than $\mathrm{ZnCl}_{2}$. Addition of aspartic acid or histidine to $\mathrm{ZnCl}_{2}$ increased the uptake but galactose or lactose decreased it. 2-Picolinic acid greatly increased the $\mathrm{Zn}$ uptake but 4-picolinic acid reduced it.

3. When incubated with intestinal sacs after incorporation into a synthetic rat diet, only $\mathrm{ZnSO}_{4}$ and 2-picolinic acid increased $\mathrm{Zn}$ uptake compared with $\mathrm{ZnCl}_{2}$, but zinc citrate and 4-picolinic acid still tended to decrease it.

4. Metabolic balance studies showed no significant differences in the faecal excretion, total excretion or retention of $\mathrm{Zn}$ between rats receiving diets containing different forms of $\mathrm{Zn} . \mathrm{ZnSO}_{4}$, zinc citrate and particularly 2-picolinic acid increased the urinary excretion of $\mathrm{Zn}$.

5. The significance of these results is discussed in relation to the suitability of methods for investigating $\mathrm{Zn}$ absorption and the importance of $\mathrm{Zn}$-binding ligands.
\end{abstract}

Many methods are available for measuring the absorption of dietary minerals and most of them have been applied to the study of zinc uptake. Although the metabolic balance technique is probably the ultimate standard of reference, it is a time-consuming and expensive procedure, and it does not provide any information about the site of absorption. Alternative methods have therefore been developed to investigate mineral absorption in greater detail. These include the use of artificial membranes (Miller et al. 1981), everted gut sacs (Pearson et al. 1966), ligated intestinal loops (Schwarz \& Kirchgessner, 1978) and intestinal perfusion techniques (Smith et al. 1978).

Several dietary constituents have been found to influence the availability of ingested $\mathrm{Zn}$, with substances like calcium, phosphate and phytate reducing it (O'Dell \& Savage, 1960; Likuski \& Forbes, 1965; House et al. 1982). We wanted to examine the effect of a wide range of substances on $\mathrm{Zn}$ absorption and used the uptake by everted sacs of rat intestine as an initial screen. The compounds that produced the most interesting changes were then studied more fully by metabolic balance methods in living rats.

\section{EXPERIMENTA L}

\section{Materials and methods}

All investigations were carried out using adult male Wistar albino rats from the stock colony weighing $220-250 \mathrm{~g}$. They had been housed in galvanized cages and maintained on commercial animal cubes (41B; E. Dixon \& Sons Ltd, Ware) and tap water ad lib.

The composition of the basic $\mathrm{Zn}$-free diet is given in Table 1. By using casein of low vitamin content (Koch-Light Laboratories Ltd, Colnbrook) and Analar chemicals in the salt mixture a background $\mathrm{Zn}$ concentration of $3 \mathrm{mg} / \mathrm{kg}$ diet was obtained. Individual diets were prepared from salt mixtures containing sufficient zinc chloride, zinc sulphate, zinc phosphate or zinc citrate to give an additional $\mathrm{Zn}$ concentration of $50 \mathrm{mg} / \mathrm{kg}$ diet. Further diets were prepared containing $\mathrm{ZnCl}_{2}$ + histidine, $\mathrm{ZnCl}_{2}+$ 2-picolinic acid and $\mathrm{ZnCl}_{2}+4$ picolinic acid at a molar ratio, ligand: $\mathrm{Zn}$ of $50: 1$. 
Table 1. Composition $(\mathrm{g} / \mathrm{kg})$ of zinc-free diet

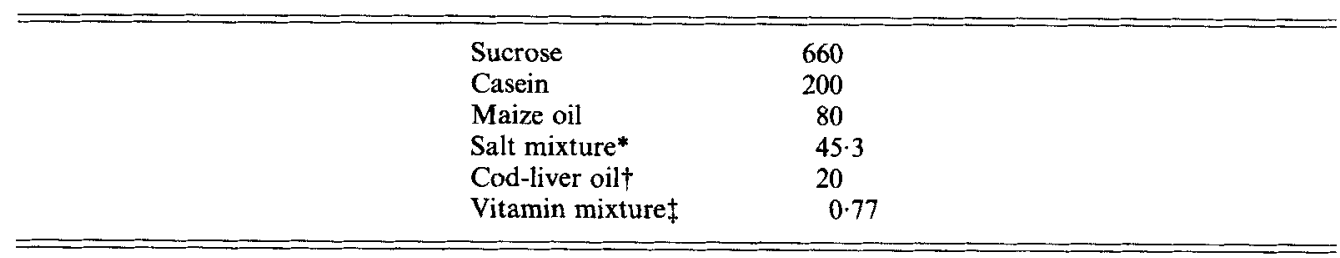

* Composition (g/kg): $\mathrm{CaCO}_{3} 188, \quad \mathrm{NaH}_{2} \mathrm{PO}_{4} \cdot 2 \mathrm{H}_{2} \mathrm{O} 200, \mathrm{~K}_{2} \mathrm{CO}_{3} 89, \quad \mathrm{FeSO}_{4} \cdot 7 \mathrm{H}_{2} \mathrm{O} 5, \quad \mathrm{MgCl}_{2} 80$, $\mathrm{MnCl}_{2} .4 \mathrm{H}_{2} \mathrm{O} 2 \cdot 6, \mathrm{NaI} 0 \cdot 52, \mathrm{NaF} 0 \cdot 40$, $\mathrm{CuSO}_{4} .5 \mathrm{H}_{2} \mathrm{O} 0 \cdot 28$.

$\dagger$ Provided the following $(\mu \mathrm{g} / \mathrm{kg}$ diet $)$ : vitamin A 3600 , vitamin D 42.5 .

$¥$ Provided the following $(\mathrm{mg} / \mathrm{kg}$ diet $)$ : choline chloride $360, p$-aminobenzoic acid 120, myo-inositol 120 , nicotinic acid 120 , pantothenic acid 24 , riboflavin $9 \cdot 6$, thiamin $4 \cdot 8$, pyridoxine $4 \cdot 8$, folic acid $2 \cdot 4$, biotin $0 \cdot 96$, menaphthone 0.096 , cyanocobalamin 0.048.

\section{Incubation of intestinal sacs}

Rats in the post-absorptive state were killed by cervical dislocation at 09.30 hours, the whole small intestine removed immediately and rinsed free of contents with distilled water. Three segments of $30-40 \mathrm{~mm}$ length were cut from each region of the intestine. Duodenal segments were taken from the first $120 \mathrm{~mm}$ posterior to the pylorus and ileal segments from the region $120-240 \mathrm{~mm}$ anterior to the ileo-caecal junction. They were placed immediately in

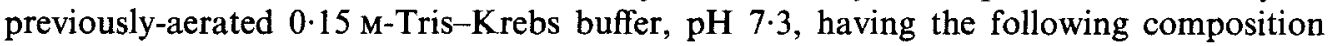
(mM): Tris-hydrochloride $15 \cdot 5$, sodium chloride $120 \cdot 7$, potassium chloride $5 \cdot 6$, calcium chloride $2 \cdot 5$, magnesium chloride $1 \cdot 2$, glucose $11 \cdot 5$.

Each segment was inverted on a Pasteur pipette and one end tied with cotton. The sac was filled with $\mathrm{Zn}$-free $0.15 \mathrm{M}$-Tris-Krebs buffer, $\mathrm{pH} 7 \cdot 3$, from a syringe until slightly distended and the other end tied. Sacs were incubated for $30 \mathrm{~min}$ at $37^{\circ}$ in the same buffer containing different $\mathrm{Zn}$ salts at a constant $\mathrm{Zn}$ concentration of $3 \times 10^{-4} \mathrm{M}$. Organic compounds were always added at a concentration of $1.5 \times 10^{-2} \mathrm{M}$. The $\mathrm{pH}$ of each medium was checked and if necessary adjusted to 7.3. All media were previously saturated with air and bubbled continuously with air during incubation; the incubation commenced within 15 min of removing the intestine. At the end of the incubation period sacs were sectioned and the contents drained for analysis. Trial measurements were made with incubation media at $\mathrm{pH} 6.4$ and 8.3 using the same medium, except that in the former case the Trishydrochloride buffer was replaced by Hepes-potassium hydroxide.

The seven synthetic diets were suspended in $0.15 \mathrm{M}$-Tris-Krebs buffer, $\mathrm{pH} 7.3$, and incubated with intestinal sacs in the same way. Measurements were made with dietary concentrations of 40 and $400 \mathrm{~g} / \mathrm{l}$ medium, which gave $\mathrm{Zn}$ concentrations of $3 \times 10^{-5}$ and $3 \times 10^{-4} \mathrm{M}$ respectively. The sacs were filled with $\mathrm{Zn}$-free buffer as described previously.

\section{Metabolic balance measurements}

Rats were housed individually in stainless-steel metabolism cages at $20^{\circ}$ in a room with $12 \mathrm{~h}$ light- $12 \mathrm{~h}$ dark periods. They were allocated randomly to different groups and each rat received $18 \mathrm{~g}$ of the appropriate diet/d with distilled water ad lib. Preliminary trials had shown that this was the maximum amount of food they would totally consume. After $7 \mathrm{~d}$ equilibration, balance collections were made over a $4 \mathrm{~d}$ period and the rats were weighed at the beginning and end of this period. The daily urine and faecal collections from each rat were pooled over the balance period. At the end of the balance, blood was obtained by cardiac puncture and heparinized plasma was separated for $\mathrm{Zn}$ determination. 


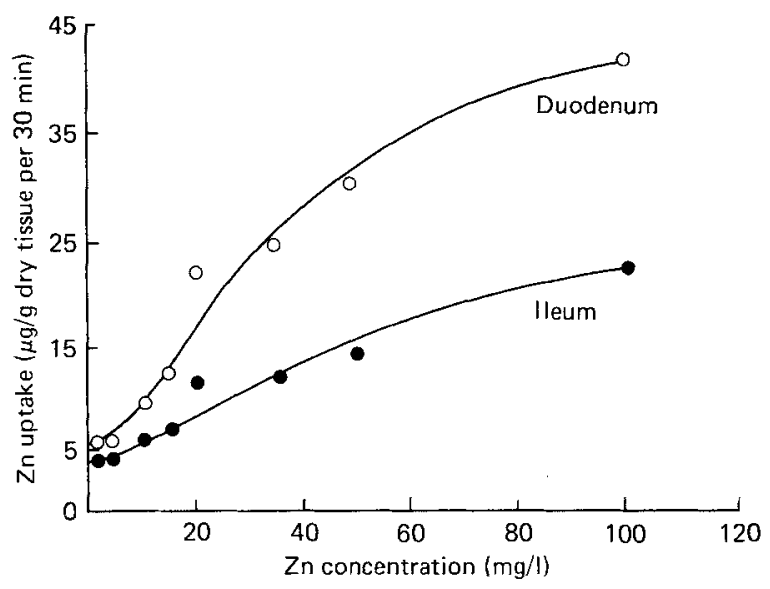

Fig. 1. Effect of zinc concentration $(\mathrm{mg} / \mathrm{l})$ in the medium on $\mathrm{Zn}$ uptake $(\mu \mathrm{g} / \mathrm{g}$ dry weight of tissue per $30 \mathrm{~min}$ ) by everted sacs of rat duodenum and ileum incubated in vitro.

\section{Analytical methods}

Intestinal sacs were dried overnight at $105^{\circ}$ to obtain their dry weight. Food and faecal collections were dried in the same way, then ashed in silica crucibles by heating in a muffle furnace at $500^{\circ}$ for $16 \mathrm{~h}$; the ash was dissolved in $2 \mathrm{M}-\mathrm{HCl}$. Plasma was deproteinized with hydrochloric and trichloroacetic acids as described by Gubler et al. (1952).

$\mathrm{Zn}$ was determined in sac contents, urine, solutions of food and faecal ash, and deproteinized plasma with a Pye Unicam SP 90 atomic absorption spectrophotometer; all solutions contained $0.1 \mathrm{M}-\mathrm{HCl}$ to prevent interference by other constituents of the samples. Glucose was estimated in some sac contents by the glucose oxidase method (Fleming \& Pegler, 1963). The statistical significance of differences was assessed by Student's $t$ test.

\section{RESULTS}

\section{Conditions affecting $Z n$ uptake by intestinal sacs}

Preliminary studies using duodenal and ileal sacs containing buffer without either glucose or $\mathrm{Zn}$ showed that the preparations maintained active glucose uptake for $2.5 \mathrm{~h}$ and the relationship between the rate of $\mathrm{Zn}$ uptake and the period of incubation was linear for approximately $45 \mathrm{~min}$. Fig. 1 shows that the $\mathrm{Zn}$ uptake was dependent on the external concentration of $\mathrm{Zn}$ and was always greater with duodenal than with ileal sacs. In view of these observations, standard conditions involving an incubation period of $30 \mathrm{~min}$ with an external $\mathrm{Zn}$ concentration of $20 \mathrm{mg} / \mathrm{l}\left(3 \times 10^{-4} \mathrm{M}\right)$ were adopted for comparative purposes to obtain the most sensitive response.

Further trials showed that the uptake from $\mathrm{ZnCl}_{2}$ was influenced by the $\mathrm{pH}$ of the incubation medium. Lowering the $\mathrm{pH}$ from $7 \cdot 3$ to 6.4 reduced the $\mathrm{Zn}$ uptake by duodenal sacs (mean with SE) from $23.4(0.9)$ to $15.2(1.5) \mu \mathrm{g} / \mathrm{g}$ dry weight of tissue per $30 \mathrm{~min}$ $(P<0.001)$ and raising the $\mathrm{pH}$ from 7.3 to 8.3 lowered the uptake by ileal sacs from 13.0 $(0.5)$ to $8.6(1.1) \mu \mathrm{g} / \mathrm{g}$ dry weight of tissue per $30 \mathrm{~min}(P<0.01)$. A uniform $\mathrm{pH}$ of 7.3 was therefore used for measurements with different $\mathrm{Zn}$ salts and organic compounds.

\section{Effect of anions and organic ligands on uptake by intestinal sacs}

Table 2 shows that the rate of $\mathrm{Zn}$ uptake from different salts varied considerably. Taking $\mathrm{ZnCl}_{2}$ as the reference, because it is likely to be the predominant matrix after exposure to 
Table 2. Zinc uptake by duodenal and ileal sacs incubated in buffer containing different $\mathrm{Zn}$ salts and organic ligands

\begin{tabular}{|c|c|c|c|c|c|}
\hline \multirow{3}{*}{$\begin{array}{l}\text { Chemical form } \\
\text { of } \mathrm{Zn}\end{array}$} & \multirow{3}{*}{$\begin{array}{c}\text { No. of } \\
\text { observations }\end{array}$} & \multicolumn{4}{|c|}{$\mathrm{Zn}$ uptake $(\mu \mathrm{g} / \mathrm{g}$ dry weight tissue in $30 \mathrm{~min})$} \\
\hline & & \multicolumn{2}{|c|}{ Duodenum } & \multicolumn{2}{|c|}{ Ileum } \\
\hline & & Mean & SEM & Mean & SEM \\
\hline $\mathrm{ZnCl}_{2}$ & 50 & 23.4 & 0.9 & $13 \cdot 0$ & 0.5 \\
\hline $\mathrm{ZnSO}_{4}$ & 16 & $34 \cdot 5^{* * *}$ & $2 \cdot 1$ & $15 \cdot 4^{*}$ & 1.0 \\
\hline $\mathrm{Zn}_{3}\left(\mathrm{PO}_{4}\right)_{2}$ & 8 & $14 \cdot 7 * * *$ & $1 \cdot 3$ & $13 \cdot 2$ & 0.9 \\
\hline $\mathrm{Zn}$ acetate & 8 & $35 \cdot 5^{* * *}$ & 4.7 & $14 \cdot 2$ & 1.0 \\
\hline Zn citrate & 6 & $11.9 * * *$ & $1 \cdot 0$ & $9 \cdot 6^{* *}$ & 0.2 \\
\hline $\mathrm{ZnCl}_{2}+$ aspartic acid & 8 & $27 \cdot 4^{*}$ & 1.8 & $17 \cdot 1^{* *}$ & $1 \cdot 3$ \\
\hline $\mathrm{ZnCl}_{2}+$ cysteine & 8 & $19 \cdot 3$ & $2 \cdot 3$ & $13 \cdot 5$ & $1 \cdot 0$ \\
\hline $\mathrm{ZnCl}_{2}+$ glutamic acid & 8 & $22 \cdot 3$ & $1 \cdot 9$ & $13 \cdot 4$ & 1.2 \\
\hline $\mathrm{ZnCl}_{2}$, histidine & 8 & $35 \cdot 7 * * *$ & $2 \cdot 1$ & $17 \cdot 7^{* *}$ & 2.9 \\
\hline $\mathrm{ZnCl}_{2}+$ tryptophan & 8 & $20 \cdot 3$ & 1.6 & $10 \cdot 7$ & 0.7 \\
\hline $\mathrm{ZnCl}_{2}+$ galactose & 8 & $15 \cdot 5^{* * *}$ & 1.7 & $12 \cdot 3$ & 0.6 \\
\hline $\mathrm{ZnCl}_{2}+$ lactose & 8 & $15 \cdot 8^{* * *}$ & 0.8 & $12 \cdot 8$ & 1.2 \\
\hline $\mathrm{ZnCl}_{2}+2$-picolinic acid & 5 & $94 \cdot 8^{* * *}$ & $12 \cdot 2$ & $33 \cdot 3^{* * *}$ & $2 \cdot 2$ \\
\hline $\mathrm{ZnCl}_{2}+4$-picolinic acid & 4 & $11 \cdot 1^{* * *}$ & 1.6 & $8 \cdot 2^{* *}$ & 0.7 \\
\hline
\end{tabular}

Value significantly different from that for $\mathrm{ZnCl}_{2}:{ }^{*} P<0.05,{ }^{* *} P<0.01,{ }^{* * *} P<0.001$.

Table 3. Zinc uptake by duodenal and ileal sacs incubated with synthetic diets containing different $\mathrm{Zn}$ salts and organic ligands

(Mean values with their standard errors for eight observations in each group)

\begin{tabular}{|c|c|c|c|c|c|c|c|c|}
\hline \multirow{4}{*}{$\begin{array}{l}\text { Diet concentration } \\
(\mathrm{g} / \mathrm{l} \text { medium }) \dagger \ldots \\
\text { Chemical form of } \mathrm{Zn}\end{array}$} & \multicolumn{8}{|c|}{$\mathrm{Zn}$ uptake $(\mu \mathrm{g} / \mathrm{g}$ dry weight tissue in $30 \mathrm{~min})$} \\
\hline & \multicolumn{4}{|c|}{ Duodenum } & \multicolumn{4}{|c|}{ Ileum } \\
\hline & \multicolumn{2}{|c|}{40} & \multicolumn{2}{|c|}{400} & \multicolumn{2}{|c|}{40} & \multicolumn{2}{|c|}{400} \\
\hline & Mean & SEM & Mean & SEM & Mean & SEM & Mean & SEM \\
\hline $\mathrm{ZnCl}_{2}$ & $6 \cdot 36$ & 0.22 & $9 \cdot 43$ & 0.35 & $5 \cdot 25$ & 0.23 & $5 \cdot 36$ & $0 \cdot 12$ \\
\hline $\mathrm{ZnSO}_{4}$ & $8 \cdot 87^{* * * *}$ & 0.29 & $10 \cdot 51^{*}$ & $0 \cdot 19$ & $5 \cdot 42$ & $0 \cdot 10$ & $8 \cdot 17^{* *}$ & $0 \cdot 20$ \\
\hline $\mathrm{Zn}_{3}\left(\mathrm{PO}_{4}\right)_{2}$ & 6.68 & 0.24 & $9 \cdot 40$ & 0.19 & $5 \cdot 31$ & $0 \cdot 21$ & $5 \cdot 28$ & 0.08 \\
\hline $\mathrm{Zn}$ citrate & $5 \cdot 40^{*}$ & $0 \cdot 19$ & $9 \cdot 23$ & 0.37 & $5 \cdot 10$ & 0.07 & 5.39 & $0 \cdot 19$ \\
\hline $\mathrm{ZnCl}_{2}+$ histidine & $6 \cdot 40$ & 0.42 & $10 \cdot 23$ & 0.27 & 5.54 & 0.27 & 6.08 & 0.35 \\
\hline $\mathrm{ZnCl}_{2}+2$-picolinic acid & $10 \cdot 48^{* * *}$ & 0.41 & $41 \cdot 75^{* * *}$ & $2 \cdot 14$ & $11 \cdot 69^{* * *}$ & 0.42 & $27 \cdot 15^{* * *}$ & $3 \cdot 12$ \\
\hline $\mathrm{ZnCl}_{2}+4$-picolinic acid & $5 \cdot 35^{* *}$ & $0 \cdot 14$ & $9 \cdot 15$ & 0.23 & $5 \cdot 29$ & 0.19 & $5 \cdot 43$ & 0.15 \\
\hline
\end{tabular}

Value significantly different from that for $\mathrm{ZnCl}_{2}:{ }^{*} P<0.05,{ }^{* *} P<0.01, * * * P<0.001$.

$\uparrow$ Synthetic diet was suspended in $0.15 \mathrm{M}$-Tris-Krebs buffer, pH 7.3.

the gastric juice in vivo, sulphate and acetate significantly increased the uptake in duodenum, but phosphate and citrate decreased it. Among the organic constituents of foods that were examined, aspartic acid and histidine enhanced $\mathrm{Zn}$ uptake, galactose and lactose depressed it, and cysteine, glutamic acid and tryptophan had no significant effect.

$\mathrm{Zn}$ uptake was consistently lower with ileum than duodenum (Table $2, P<0.001$ ) and the influence of different anions and organic substances was less marked. With ileum only sulphate, citrate, aspartic acid and histidine produced significant effects, but the changes were consistent with those observed in duodenum. 


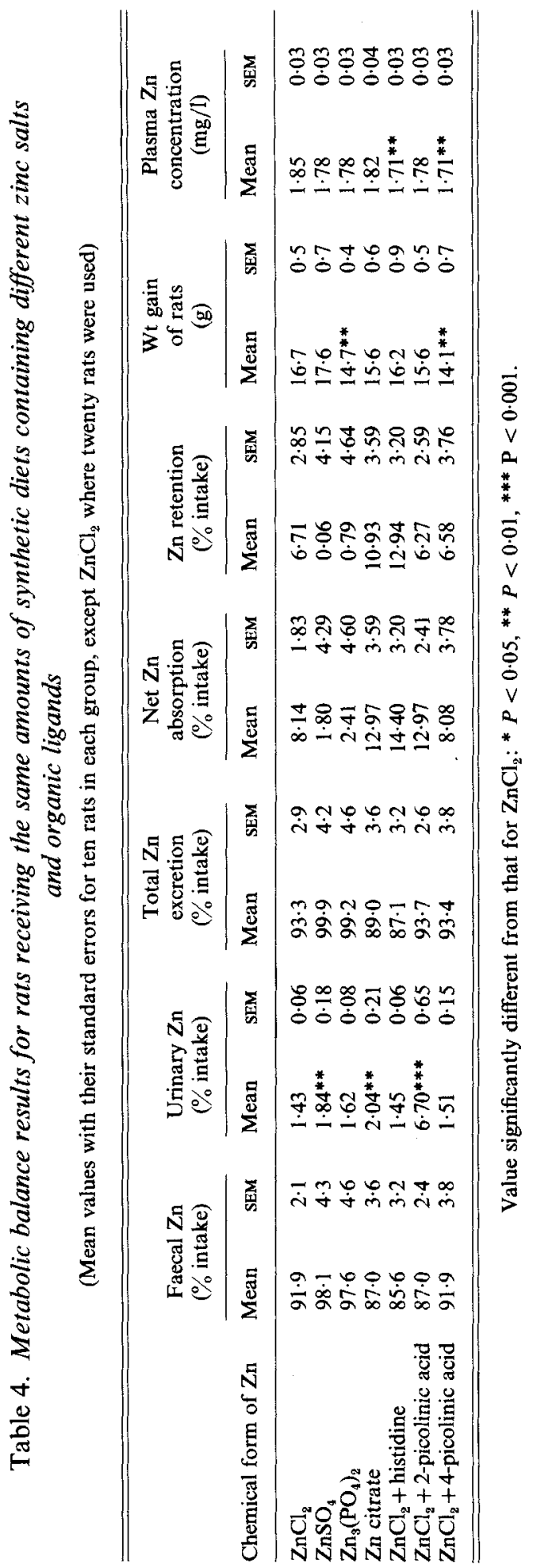


The contrasting response to the two isomers of picolinic acid (pyridine carboxylic acid) is striking. The 2-isomer approximately trebled $\mathrm{Zn}$ uptake by both duodenal and ileal sacs, but the 4-isomer almost halved it within both regions of the intestine.

After incorporation into the whole diet the effects of the different $\mathrm{Zn}$ salts and organic ligands were less marked than those observed in simple buffer solution. Only the sulphate and 2-picolinic acid increased $\mathrm{Zn}$ uptake by both duodenum and ileum (Table 3), although citrate and 4-picolinic acid decreased the uptake by duodenum.

\section{Measurement of $\mathrm{Zn}$ balance in vivo}

The $\mathrm{Zn}$ concentration determined by analysis was almost constant in all seven diets at $53.2(\mathrm{se} 0.3) \mathrm{mg} / \mathrm{kg}$. This gave a mean $\mathrm{Zn}$ intake during the $4 \mathrm{~d}$ balance period of $3.83 \mathrm{mg} / \mathrm{rat}$. The amounts of $\mathrm{Zn}$ retained and excreted by different routes have been related to the dietary intake in Table 4 in order to facilitate interpretation.

Faecal output was the predominant route of $\mathrm{Zn}$ loss, averaging 91.0 (SE 1.8)\% of the intake, and the urinary excretion only amounted to $1-2 \%$ of the intake in most cases. No statistically-significant differences from $\mathrm{ZnCl}_{2}$ were observed between the faecal excretion, total excretion or retention of $\mathrm{Zn}$ on the different diets. The only significant differences found in $\mathrm{Zn}$ metabolism were increased rates of urinary excretion by rats receiving the sulphate, citrate or particularly 2-picolinic acid. This increased excretion did not, however, correlate with the lowered plasma levels of $\mathrm{Zn}$ in rats receiving histidine or 4-picolinic acid. All rats were in positive balance for $\mathrm{Zn}$ and increasing in body-weight although the rate of growth was reduced in those receiving diets containing $\mathrm{Zn}_{3}\left(\mathrm{PO}_{4}\right)_{2}$ or 4-picolinic acid.

\section{DISCUSSION}

The results of the present investigation show that the rate of $\mathrm{Zn}$ uptake per unit weight of tissue was consistently greater with duodenal than with ileal sacs, usually by a factor of two. This observation together with the effect of $\mathrm{pH}$ on $\mathrm{Zn}$ uptake, which was greater at 7.3 than at either 6.4 or 8.3 , indicates that $\mathrm{Zn}$ is transferred across the gut wall more efficiently in the duodenum than the ileum and is likely to be most efficient in the part of the duodenum where the $\mathrm{pH}$ of the lumen contents approaches neutrality. However, this conclusion does not necessarily imply that the duodenum is the most important site of $\mathrm{Zn}$ absorption in the living animal, because the greater length of the ileum and the longer period of its contact with the intestinal contents could quantitatively outweigh the more efficient uptake in the duodenum. This problem has been investigated by several groups using a variety of techniques in vivo (Van Campen \& Mitchell, 1965; Methfessel \& Spencer, 1973; Davies, 1980) and it appears that the duodenum is the major site of $\mathrm{Zn}$ absorption.

Incubation with intestinal sacs and particularly duodenal sacs in vitro appears to provide a rapid and useful method for screening substances that may influence $\mathrm{Zn}$ absorption. The relative effects of the various anions and organic ligands were qualitatively consistent during the three stages of the present study, but their quantitative effects were progressively reduced on moving from incubation with sacs in simple buffer solution, to incubation with sacs when incorporated in a complete diet, to metabolic balance studies in vivo. This was probably due to interaction with components other than $\mathrm{Zn}$ when mixed in the diet and the reduced sensitivity obtained during balance studies in whole animals compared with the simpler intestinal sac procedure.

Wide variations in $\mathrm{Zn}$ absorption have been reported in metabolic balance studies (Becker \& Hoekstra, 1971) but the range of net absorption from 2 to $15 \%$, with a mean value of $9 \%$, that we observed is consistent with the results of other studies in rats (Ballou \& Thompson, 1961; Heth \& Hoekstra, 1965). Measurements of this type will include the faecal excretion of endogenous $\mathrm{Zn}$, which may be considerable (Weigand \& Kirchgessner, 1978; 
Evans et al. 1979), and they therefore underestimate the true absorption of ingested $\mathrm{Zn}$. Another limitation of the balance technique is the probable experimental error of $5-10 \%$. With a substance like $\mathrm{Zn}$, where the faecal excretion amounts to approximately $90 \%$ of the dietary intake, it will require a very large proportionate increase in the net absorption to make the difference statistically significant. Although the metabolic balance is usually regarded as the standard of reference, because it is the only procedure that uses intact animals, it is probably too insensitive in this type of situation to detect differences that are likely to be of biological significance.

$\mathrm{ZnSO}_{4}$ seems to be the inorganic salt that is most efficiently utilized. Its uptake by intestinal sacs was greater than from the chloride in both simple buffer solution and after incorporation into the diet, and the increased urinary excretion of $\mathrm{Zn}$ observed during the balance studies in rats receiving $\mathrm{ZnSO}_{4}$ is consistent with this. The effect of amino acids that have the potential to chelate $\mathrm{Zn}$ is surprisingly variable. Only histidine and to a lesser extent aspartic acid increased its uptake from simple buffer, which confirms the influence of histidine reported by Giroux \& Prakash (1977) and Schwarz \& Kirchgessner (1975, 1978), but the effect was masked after incorporation into the diet. Cysteine, tryptophan and glutamic acid had no significant effect in our system, but Schwarz \& Kirchgessner (1975) and Oestreicher \& Cousins (1982) have obtained conflicting evidence about the effect of the first two of these amino acids on $\mathrm{Zn}$ uptake. The inhibitory influence of galactose and lactose on $\mathrm{Zn}$ uptake contrasts with their stimulatory effect on the absorption of calcium and magnesium.

In view of the controversy about the roles of citrate (Lönnerdal et al. 1980) and picolinate (Evans \& Johnson, 1980) in enhancing the availability of $\mathrm{Zn}$ from human milk we examined their effects during the present study. The 2-isomer of picolinic acid, which is the metabolite of tryptophan, greatly increased $\mathrm{Zn}$ uptake by duodenal and ileal sacs from both simple buffer and complete diet, whereas the 4-isomer had the opposite effect. Citrate, however, inhibited $\mathrm{Zn}$ uptake from buffer in both regions of the intestine and showed a similar but less marked tendency after incorporation into the diet. These results conflict with the observations of Jackson et al. (1981) who found that citrate increased the absorption of ${ }^{65} \mathrm{Zn}$ whereas picolinic acid did not. It may be significant that their studies were conducted with fasting rats while the tissues we used were always obtained from animals in the normal post-absorptive state.

The results from our intestinal sac studies therefore indicate that 2-picolinic acid has the potential to enhance the absorption of dietary $\mathrm{Zn}$ in the rat whereas citric acid does not, irrespective of their occurrence in milk. The marked increase in urinary $\mathrm{Zn}$ excretion by rats receiving diets containing 2-picolinic acid, however, suggests that this ligand may merely enhance the turnover of $\mathrm{Zn}$ rather than increase its utilization in the body.

The authors thank the Science and Engineering Research Council and Farley Health Products Ltd for a CASE award to C.J.S.

REFERENCES

Ballou, J. E. \& Thompson, R. C. (1961). Health Physics 6, 6-18.

Becker, W. M. \& Hoekstra, W. G. (1971). In Intestinal Absorption of Metal Ions, Trace Elements and Radionucleotides, pp. 229-256 [S. C. Skoryna and D. Waldron-Edwards, editors]. New York: Pergamon Press.

Davies, N. T. (1980). British Journal of Nutrition 43, 189-203.

Evans, G. W. \& Johnson, P. E. (1980). Pediatric Research 14, 876-880.

Evans, G. W., Johnson, E. C. \& Johnson, P. E. (1979). Journal of Nutrition 109, 1258-1264.

Fleming, I. D. \& Pegler, H. F. (1963). Analyst, London 88, 967-968.

Giroux, E. G. \& Prakash, N. J. (1977). Journal of Pharmaceutical Sciences 66, 391-395.

Gubler, C. J., Lahey, M. E., Ashenbrucker, H., Cartwright, G. E. \& Wintrobe, M. M. (1952). Journal of Biological Chemistry 196, 209-220. 
Heth, D. A. \& Hoekstra, W. G. (1965). Journal of Nutrition 85, 367-374.

House, W. A., Welch, R. M. \& Van Campen, D. R. (1982). Journal of Nutrition 112, 941-953.

Jackson, M. J., Jones, D. A. \& Edwards, R. H. T. (1981). British Journal of Nutrition 46, 15-27.

Likuski, H. J. A. \& Forbes, R. M. (1965). Journal of Nutrition 85, 230-234.

Lönnerdal, B., Stanislowski, A. G. \& Hurley, L. S. (1980). Journal of Inorganic Biochemistry 12, 71-78.

Methfessel, A. H. \& Spencer, H. (1973). Journal of Applied Physiology 34, 58-62.

Miller, D. D., Schricker, B. R., Rasmussen, R. R. \& Van Campen, D. R. (1981). American Journal of Clinical Nutrition 34, 2248-2256.

O'Dell, B. L. \& Savage, J. E. (1960). Proceedings of the Society for Experimental Biology and Medicine 103, $304-306$.

Oestreicher, P. \& Cousins, R. J. (1982). Journal of Nutrition 112, 1978-1982.

Pearson, W. N., Schwink, T. \& Reich, M. (1966). In Zinc Metabolism, pp. 239-249 [A. S. Prasad, editor]. Springfield, Ill.: C. C. Thomas.

Schwarz, F. J. \& Kirchgessner, M. (1975). Zeitschrift fuer Tierphysiologie, Tierernaehrung und Futtermittelkunde $35,257-266$.

Schwarz, F. J. \& Kirchgessner, M. (1978). In Trace Element Metabolism in Man and Animals, vol. 3, pp. 110-115

[M. Kirchgessner, editor]. Freising-Weihenstaphen, West Germany: Arbeitskreis Tierenahrungsforchung Weihenstephan.

Smith, K. T., Cousins, R. J., Silbon, B. L. \& Failla, M. L. (1978). Journal of Nutrition 108, $1849-1857$.

Van Campen, D, R, \& Mitchell, E. A. (1965). Journal of Nutrition 86, 120-124.

Weigand, E. \& Kirchgessner, M. (1978). Nutrition and Metabolism 22, 101-112. 